\title{
PENGARUH LITERASI EKONOMI, KELOMPOK TEMAN SEBAYA DAN KONTROL DIRI TERHADAP PERILAKU PEMBELIAN IMPULSIF UNTUK PRODUK FASHION DI ONLINE SHOP PADA MAHASISWA JURUSAN PENDIDIKAN EKONOMI UNDIKSHA
}

\author{
Indah Pratiwi \\ Program Studi Pendidikan Ekonomi, Fakultas Ekonomi \\ Universitas Pendidikan Ganesha \\ Singaraja, Indonesia \\ e-mail: pratiwiindah431@ymail.com
}

\begin{abstract}
Abstrak
Penelitian ini bertujuan untuk mengetahui pengaruh parsial maupun simultan literasi ekonomi, kelompok teman sebaya dan kontrol diri terhadap perilaku pembelian impulsif produk fashion di online shop pada mahasiswa Jurusan Pendidikan Ekonomi Undiksha. Jenis penelitian ini merupakan penelitian kausal. Populasi dalam penelitian ini adalah mahasiswa Jurusan Pendidikan Ekonomi yang berjumlah 156 orang dengan jumlah sampel 61 orang dan diambil dengan teknik Purposive Sampling. Data dikumpulkan dengan menggunakan metode dokumentasi dan kuesioner. Data dianalisis dengan menggunakan "t test", " $F$ test" dan analisis regresi linier berganda. Hasil penelitian ini menunjukkan (1) literasi ekonomi berpengaruh positif terhadap perilaku pembelian impulsif produk fashion sebesar 11.442 , (2) kelompok teman sebaya berpengaruh positif terhadap perilaku pembelian impulsif produk fashion sebesar 2,707, (3) kontrol diri berpengaruh positif terhadap perilaku pembelian impulsif produk fashion sebesar 1,714, (4) literasi ekonomi, kelompok teman sebaya dan kontrol diri berpengaruh secara signifikan terhadap perilaku pembelian impulsif produk fashion mahasiswa Jurusan Pendidikan Ekonomi Undiksha sebesar 98,012.
\end{abstract}

\section{Kata kunci : Literasi Ekonomi, Kelompok Teman Sebaya, Kontrol Diri, Perilaku Pembelian Impulsif Abstract}

This research was aimed at knowing the influence of economy literacy, colleague group and self-control upon impulsive buying of fashion product for economy education students of Undiksha whether it was partially influenced or simultaneously. The design of this research was causal research. The population of this research is economy education students was totally 156 . The sample taken was 61 students by using Purposive Sampling. The data was collected through documentation and questionnaire method. The technique of data analysis used in this study was " $t$ test", " $F$ test" and multiple linear regression analysis. The result of this study showed that (1) economy literacy was positively influenced the impulsive buying of fashion product with the amount 11.442, (2) colleague group was positively affected the impulsive buying of fashion product with the amount 2,707 , (3) self-control also gave positive impact toward the impulsive buying of fashion product with the amount 1,714 (4) economy literacy, colleague group, and self-control were significantly influenced the impulsive buying of fashion product for economy education students of Undiksha with the amount 98,012.

Key Words : Economy Literacy, Colleague Group, Self-control, Impulsive buying 


\section{PENDAHULUAN}

Kegiatan belanja saat ini bukan hanya sekedar untuk memenuhi kebutuhan hidup tetapi kegiatan belanja saat ini sudah menjadi gaya hidup. Kemudahan konsumen dalam melakukan kegiatan belanja memunculkan fenomena yang cukup menarik dalam masyarakat. Fenomena tersebut adalah fenomena belanja yang dilakukan masyarakat secara tidak terencana atau sering disebut juga dengan istilah pembelian impulsif. Dalam hal ini mahasiswa dikategorikan remaja tingkat akhir dengan kisaran usia 18 sampai 22 tahun yang memiliki kemampuan berkonsumsi yang tinggi. Apabila mahasiswa dalam berbelanja tidak memiliki perencanaan pada awalnya dan irasional maka akan cenderung berperilaku konsumtif.

Dari 30 mahasiswa Jurusan

Pendidikan Ekonomi yang peneliti jadikan sampel observasi awal, dapat disimpulkan bahwa 30 mahasiswa tersebut memiliki kecenderungan melakukan perilaku impulsif ketika membeli produk di online shop. Sesuai yang disampaikan Mangkunegara (2009: 59), "mahasiswa yang diasumsikan sebagai remaja tingkat akhir memiliki karakteristik yaitu mudah terbujuk rayuan iklan, tidak berfikir hemat, mudah terpengaruh oleh rayuan penjual, kurang realistis, romantis, dan mudah terbujuk (impulsif)." Dalam hal ini diperoleh keterangan pada mahasiswa saat berbelanja di online shop banyak motivasi dan persepsi lain tidak diduga yang mempengaruhi mahasiswa dalam melakukan pembelian yang sebelumnya sudah membatasi keperluan bahkan telah direncanakan. Hal tersebut berpotensi mahasiswa melakukan impulsive buying. Selanjutnya Cobb and Hoyer (dalam Bashir, dkk. 2013) mengatakan suatu pembelian impulsif terjadi apabila tidak terdapat tujuan pembelian merk tertentu atau kategori produk tertentu pada saat masuk ke dalam toko, dengan kata lain impulsif adalah pembelian yang tidak terencana dan tidak memiliki tujuan membeli terhadap produk tertentu atau pun pada kategori produk tertentu. Untuk itu mahasiswa diharapkan bisa bersifat rasional dalam melakukan pembelian. Oleh karena itu, disamping mahasiswa memiliki kontrol diri yang baik, pemahaman mahasiswa terhadap ilmu ekonomi sangat diperlukan. Pemahaman terhadap ilmu ekonomi dalam hal ini melalui proses pemahaman atas literasi ekonomi. Literasi ekonomi (pengetahuan dasar ekonomi/ melek ekonomi) merupakan salah satu implementasi dari proses pembelajaran yang merupakan suatu pilihan yang bisa digunakan oleh mahasiswa untuk menjadi konsumen yang rasional serta melalui pemahaman terhadap ilmu ekonomi ini di dalamnya akan diajarkan bagaimana menentukan pilihan dan berdasarkan pertimbangan-pertimbangan tertentu termasuk membuat pilihan. Menurut Ahman (2007: 13), "pilihan adalah suatu tindakan untuk mengambil keputusan mengenai barang yang dipilih." Literasi ekonomi penting bagi mahasiswa karena akan meminimalisir perilaku konsumtif mahasiswa dalam berkonsumsi. Menurut Adiningsih dan Kadarusman (2008: 1), "teori perilaku konsumen berkaitan dengan proses pengambilan keputusan, bagaimana seseorang konsumen memilih diantara berbagai macam alternatif (choice)."

Menurut Lisda (2010: 56), "pembelian impulsif (impulsive buying) adalah proses pembelian suatu barang, dimana pembeli tidak mempunyai niat untuk membeli sebelumnya, dapat dikatakan pembelian tanpa rencana atau pembelian seketika." Menurut Kotler \& Armstrong (2008: 159-176), "perilaku pembelian konsumen sangat dipengaruhi oleh beberapa karakteristik. Karakteristik tersebut terdiri dari faktor budaya, faktor sosial, faktor pribadi dan faktor psikologis." Menurut Prasetijo dan Ihalauw (2005:159), "indikator perilaku pembelian impulsif yaitu 1) spontanitas (spontaneity), 2) kekuatan, kompulsi dan intensitas (power, compulsion and intensity), 3) kegairahan dan stimulasi (excitement and stimulation), dan 4) ketidakpedulian akan akibat (disregard for consequences)."

Menurut Lusardi (2010) teman sebaya (peer) merupakan salah satu kunci dalam pemberian informasi sekaligus pertimbangan dalam pengambilan keputusan dalam pembelian produk. Melalui komunikasi dan informasi akan terjadi berupa perubahan pendapat, sikap dan perilaku. Perilaku belanja dan perilaku 
konsumsi individu dalam kelompok dapat dipengaruhi karena adanya informasi (informational influence) yang diterima dan dapat dipercaya dari rekan-rekan anggota dan kelompoknya. Menurut Mowen dan Minor (dalam Tatik Suryani, 2013: 165167) terdapat lima faktor penting yang dapat menjelaskan mengapa kelompok dapat mempengaruhi perilaku individu, termasuk perilaku konsumsi dan perilaku pembelian adalah sebagai berikut. (1) melalui pengaruh norma, nilai ekspresif dan informasi, (2) faktor peran dalam kelompok, (3) tuntutan untuk menyesuaikan dengan kelompok, (4) proses perbandingan sosial, (5) polarisasi kelompok.

Kontrol diri didefinisikan sebagai suatu aktivitas pengendalian tingkah laku yang berkaitan dengan bagaimana individu mengendalikan emosi serta dorongandorongan dari dalam dirinya. Kontrol diri melibatkan kemampuan untuk memanipulasi diri baik untuk mengurangi maupun meningkatkan perilakunya. Menurut Syamsul (2010:107), "kontrol diri merupakan kemampuan individu untuk mengendalikan dorongan-dorongan, baik dari dalam diri maupun dari luar diri individu." Indikator kontrol diri adalah sebagai berikut. (1) kemampuan mengontrol perilaku, (2) kemampuan mengontrol stimulus, (3) kemampuan mengantisipasi suatu peristiwa atau kejadian, (4) kemampuan menafsirkan peristiwa atau kejadian, dan kemampuan mengambil keputusan." Menurut Kotler \& Armstrong (2008: 266), "produk (product) didefinisikan sebagai segala sesuatu yang dapat ditawarkan atau diperjualbelikan kepada pasar agar menarik perhatian, akuisisi, penggunaan, atau konsumsi yang dapat memuaskan suatu keinginan atau kebutuhan." Produk fashion didefinisikan produk yang mempunyai ciri-ciri khusus yang tepat dan mewakili style yang sedang trend dalam kurun waktu tertentu. Dilanjutkan oleh Park (2006) produk impulsif kebanyakan adalah produk-produk baru, contohnya, produk dengan harga murah yang tidak terduga. Beberapa macam dari barang-barang pelanggan berasal dari pembelian tidak terencana (impulsive buying), barang-barang yang paling sering dibeli adalah pakaian, perhiasan ataupun aksesoris yang dekat dengan diri sendiri dan mendukung penampilan.

$$
\text { Selanjutnya Online Shop }
$$

merupakan sarana atau toko untuk menawarkan barang dan jasa lewat internet sehingga pengunjung Online shop dapat melhat barang-barang di toko online. Toko online atau online shop bisa dikatakan sebagai tempat berjualan yang sebagian besar aktiitasnya berlangsung secara online di internet. Online shop memberikan beragam kemudahan bagi konsumennya diantaranya adalah adanya penghematan biaya, barang bisa langsung diantar ke rumah, pembayaran dilakukan secara transfer, dan harga lebih bersaing.

\section{METODE}

Jenis penelitian yang digunakan adalah penelitian kausal yang bertujuan untuk mengetahui pengaruh literasi ekonomi, kelompok teman sebaya dan kontrol diri terhadap perilaku pembelian impulsif mahasiswa Jurusan Pendidikan Ekonomi Undiksha baik secara parsial maupun secara simultan. Populasi dalam penelitian ini adalah mahasiswa Jurusan Pendidikan Ekonomi dengan jumlah 156 mahasiswa. Sampel berjumlah 61 orang dan diambil dengan teknik Purposive Sampling. Data dikumpulkan dengan menggunakan metode dokumentasi dan kuesioner. Analisis data yang digunakan adalah " $\mathrm{t}$ test", $\mathrm{F}$ test" dan analisis regresi linier berganda. Penelitian ini menggunakan skala pengukuran yang disebut skala likert. Sebelum diisi oleh responden kuesioner/angket terlebih dahulu diuji tingkat validitas dan reliabilitasnya. Setelah valid dan reliable kuesioner diisi oleh responden dan di lakukan uji regresi linier berganda, uji t, uji $\mathrm{f}$, dan uji asumsi klasik.

\section{HASIL PENELITIAN DAN PEMBAHASAN}

1. Pengaruh Literasi Ekonomi terhadap Perilaku Pembelian Impulsif Untuk Produk Fashion Pada Mahasiswa Jurusan Pendidikan Ekonomi Undiksha

Hasil perhitungan uji t pada tabel 1.

Hasil SPSS Uji $t$ Pengaruh Literasi Ekonomi terhadap Perilaku Pembelian 
Impulsif Produk Fashion menunjukkan bahwa literasi ekonomi $\left(\mathrm{X}_{1}\right)$ berpengaruh terhadap perilaku pembelian impulsif $(\mathrm{Y})$ karena jika $t_{\text {hitung }}<t_{\text {tabel }}$ atau probabilitas $>$ 0,05 maka $\mathrm{H}_{0}$ diterima dan jika $t_{\text {hitung }}>t_{\text {tabel }}$ atau probabilitas $<0,05$ maka $\mathrm{H}_{0}$ ditolak. Hasil perhitungan yaitu 11.442, pada tabel dengan db 61 dan taraf signifikan 0,05 diperoleh

1,67022 karena $11.442>1,67022$ dan pada kolom sig probabilitas $0,000<0,05$ maka $\mathrm{H}_{0}$ ditolak maka $\mathrm{H}_{1}$ diterima berarti terdapat pengaruh dari literasi ekonomi terhadap perilaku pembelian impulsif. Adapun penjelasan di atas bisa dilihat pada tabel 1 sebagai berikut.

Tabel 1. Hasil SPSS Uji t Pengaruh Literasi Ekonomi terhadap Perilaku Pembelian Impulsif Produk Fashion

Unstandardized Standardized

Coefficients Coefficients

\begin{tabular}{|c|c|c|c|c|c|c|c|}
\hline & Model & $B$ & $\begin{array}{l}\text { Std. } \\
\text { Error }\end{array}$ & Beta & & $t$ & Sig. \\
\hline \multirow[t]{2}{*}{$\overline{1}$} & (Constant) & -2.973 & 2.441 & & & -1.218 & .228 \\
\hline & Literasiekonomi & .670 & 059 & & .731 & 11.442 & .000 \\
\hline
\end{tabular}

(Sumber : Lampiran Hasil pengolahan data dengan SPSS 17.0)

2. Pengaruh Kelompok Teman Sebaya terhadap Perilaku Pembelian Impulsif Untuk Produk Fashion Pada Mahasiswa Jurusan Pendidikan Ekonomi

Nilai $t_{\text {hitung }}$ untuk kelompok teman sebaya yaitu 2,707 , pada tabel dengan db 61 dan taraf signifikan 0,05 diperoleh 1,67022, karena $t_{\text {hitung }}>t_{\text {tabel }}$ yaitu $2,707>1,67022$ dan pada kolom sig probabilitas $0,009<0,05$ maka $\mathrm{H}_{0}$ ditolak dan $\mathrm{H}_{1}$ diterima. Dapat disimpulkan bahwa variabel kelompok teman sebaya berpengaruh positif terhadap perilaku pembelian impulsif produk fashion. Adapun penjelasan di atas bisa dilihat pada tabel 2 sebagai berikut.

Tabel 2. Hasil SPSS Uji t Pengaruh Kelompok Teman Sebaya terhadap Perilaku Pembelian Impulsif Produk Fashion

$\begin{array}{ll}\text { Unstandardized } & \text { Standardized } \\ \text { Coefficients } & \text { Coefficients }\end{array}$

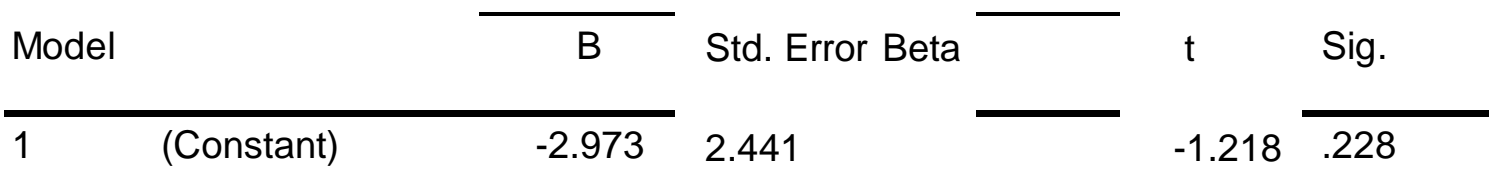

$\begin{array}{lllllll}\text { Kel. temansebaya } & .250 & 092 & .202 & 2.707 & .009\end{array}$

(Sumber : Lampiran Hasil pengolahan data dengan SPSS 17.0)

\section{Pengaruh Kontrol diri terhadap Perilaku Pembelian Impulsif Untuk Produk Fashion Pada Mahasiswa Jurusan Pendidikan Ekonomi Undiksha}

Hasil SPSS uji t di atas dapat dilihat

bahwa nilai thitunguntuk kontrol diri yaitu 1,714, pada tabel dengan db 61 dan taraf signifikan 0,05 diperoleh 1,67022, karena $t_{\text {hitung }}>t_{\text {tabel }}$ yaitu $1,714>1,67022$ dan pada kolom sig probabilitas $0,009<0,05$ maka $\mathrm{H}_{0}$ 
ditolak dan $\mathrm{H}_{1}$ diterima. Dapat disimpulkan bahwa variabel kontrol diri berpengaruh positif terhadap perilaku pembelian impulsif produk fashion. Adapun penjelasan di atas bisa dilihat pada tabel 3 sebagai berikut.

Tabel 3. Hasil SPSS Uji t Pengaruh Kontrol Diri terhadap Perilaku Pembelian Impulsif Produk Fashion Unstandardize Standardized d Coefficients Coefficients

\begin{tabular}{|c|c|c|c|c|c|c|}
\hline Model & & B & $\begin{array}{l}\text { Std. } \\
\text { Error }\end{array}$ & Beta & $\mathrm{T}$ & Sig. \\
\hline 1 & (Constant) & -2.973 & 2.441 & & -1.218 & .228 \\
\hline
\end{tabular}

$\begin{array}{lllll}\text { Kontroldiri } & .127 & 074 & .1141 .714 & .092\end{array}$

(Sumber : Lampiran Hasil pengolahan data dengan SPSS 17.0)

\section{Pengaruh Literasi Ekonomi, Kelompok Teman Sebaya dan Kontrol Diri Terhadap Perilaku Pembelian Impulsif Untuk Produk Fashion Pada Mahasiswa Jurusan Pendidikan Ekonomi Undiksha}

Berdasarkan hasil perhitungan uji signifikansi simultan (uji f) pada tabel ANOVA menggambarkan bahwa Literasi Ekonomi $\left(\mathrm{X}_{1}\right)$, Kelompok Teman Sebaya $\left(\mathrm{X}_{2}\right)$, dan Kontrol Diri $\left(\mathrm{X}_{3}\right)$ secara simultan (bersama-sama) berpengaruh terhadap Perilaku Pembelian Impulsif $(Y)$ karena dari hasil perhitungan diketahui $\mathrm{f}_{\text {hitung }}$ sebesar 98,012 dan $f_{\text {tabel }}$ sebesar 3,15 . Karena $f_{\text {hitung }}$ $>f_{\text {tabel }}$ yaitu $98,012>3,15$ dan tingkat signifikansi atau probabilitas 0,000 $<0,05$ maka $\mathrm{H}_{0}$ ditolak dan $\mathrm{H}_{1}$ diterima. Dapat disimpulkan bahwa variabel-variabel bebas yaitu literasi ekonomi, kelompok teman sebaya dan kontrol diri secara simultan (bersama-sama) berpengaruh terhadap variabel terikat yaitu perilaku pembelian impulsif. Adapun penjelasan di atas bisa dilihat pada tabel 3 sebagai berikut.

Tabel 4. Hasil SPSS Uji F Pengaruh Literasi Ekonomi, Kelompok Teman Sebaya dan Kontrol Diri terhadap Perilaku Pembelian Impulsif Produk Fashion 
ANOVA $^{\text {b }}$

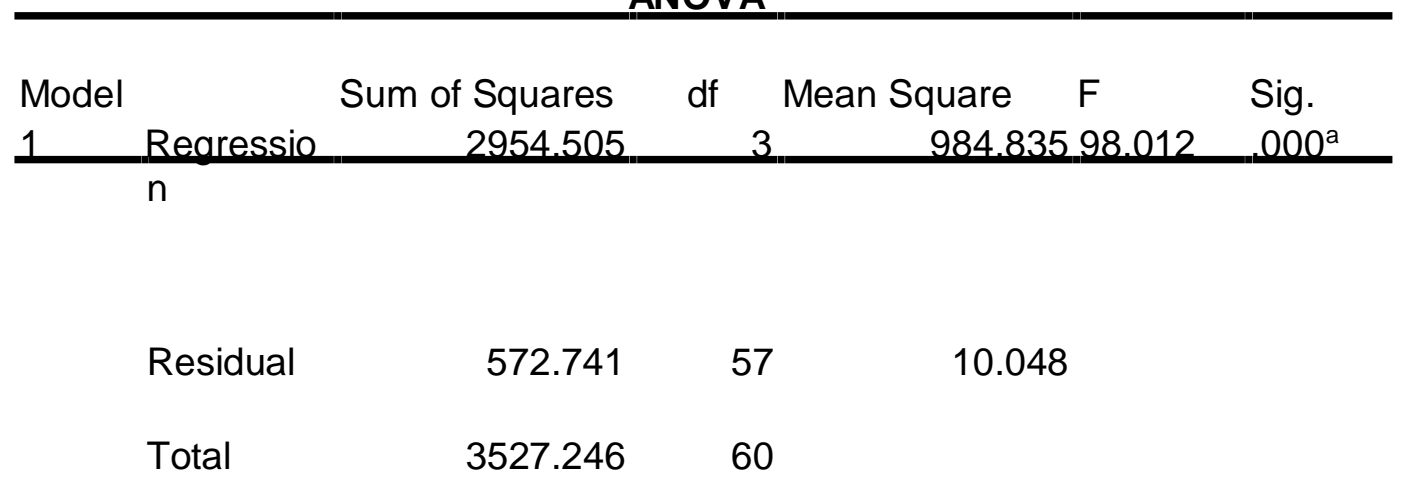

(Sumber : Lampiran Hasil pengolahan data dengan SPSS 17.0)

Untuk melihat seberapa besar pengaruh regresi. Adapun penjelasan di atas bisa masing-masing variabel bebas terhadap variabel terikat, akan terlihat pada analisis dilihat pada tabel 5 sebagai berikut.

Tabel 5. Hasil SPSS Analisis Regresi

\begin{tabular}{|c|c|c|c|c|c|c|c|}
\hline \multirow[b]{2}{*}{ Model } & \multicolumn{2}{|c|}{$\begin{array}{l}\text { Unstandardized } \\
\text { Coefficients }\end{array}$} & \multirow{2}{*}{$\begin{array}{l}\text { Standardized } \\
\text { Coefficients }\end{array}$} & \multirow[b]{2}{*}{$t$} & \multirow[b]{2}{*}{ Sig. } & \multicolumn{2}{|c|}{ Collinearity Statistics } \\
\hline & $B$ & Std. Error & & & & Tolerance & VIF \\
\hline 1 (Constant) & -2.973 & 2.441 & & -1.218 & .228 & & \\
\hline Literasiekonomi & .670 & .059 & .731 & 11.442 & .000 & .698 & 1.434 \\
\hline Kel. temansebaya & .250 & .092 & .202 & 2.707 & .009 & .510 & 1.962 \\
\hline Kontroldiri & .127 & .074 & .114 & 1.714 & .092 & .640 & 1.562 \\
\hline
\end{tabular}

(Sumber : Lampiran Hasil pengolahan data dengan SPSS 17.0)

Berdasarkan tabel coefficients dapat diketahui bentuk persamaan regresi berganda $\breve{Y}=a+b$ x yaitu $\breve{Y}=-2,973+X_{1}+X_{2}+X_{3}+\mu$. Model persamaan regresi berganda tersebut dapat menjelaskan bahwa, apabila variabel bebas yaitu literasi ekonomi mengalami kenaikan 1 satuan maka akan diikuti dengan penurunan perilaku pembelian impulsif Untuk mengetahui kelayakan penelitian ini menggunakan uji asumsi sebesar 670 satuan. Sedangkan apabila variabel bebas yaitu kelompok teman sebaya mengalami kenaikan 1 satuan akan diikuti dengan kenaikan perilaku pembelian impulsif sebesar 2,50 satuan dan apabila kontrol diri mengalami kenaikan 1 satuan akan diikuti dengan penurunan perilaku pembelian impulsif sebesar 1,27 satuan.

klasik yaitu uji Autokorelasi, Multikolinieritas dan Heteroskedastisitas.

Tabel 4. Hasil SPSS Uji Autokorelasi 


\begin{tabular}{|c|c|c|c|c|c|c|c|c|c|c|}
\hline \multirow{2}{*}{ Model } & \multirow{2}{*}{$\mathrm{R}$} & \multirow{2}{*}{$\begin{array}{c}\mathrm{R} \\
\text { Square }\end{array}$} & \multirow{2}{*}{$\begin{array}{l}\text { Adjust } \\
\text { ed R } \\
\text { Square }\end{array}$} & \multirow{2}{*}{$\begin{array}{l}\text { Std.Error } \\
\text { of the } \\
\text { Estimate }\end{array}$} & \multicolumn{5}{|c|}{ Change Statistics } & \multirow{2}{*}{$\begin{array}{l}\text { Durbin- } \\
\text { Watson }\end{array}$} \\
\hline & & & & & $\begin{array}{l}\text { R Square } \\
\text { change }\end{array}$ & $\begin{array}{l}\text { F } \\
\text { Change }\end{array}$ & $\begin{array}{l}\mathrm{df} \\
1\end{array}$ & $\begin{array}{l}d f \\
2\end{array}$ & $\begin{array}{l}\text { Sig. F } \\
\text { Change }\end{array}$ & \\
\hline 1 & $.915^{\mathrm{a}}$ & .838 & .829 & 3.170 & .838 & 98.012 & 3 & 57 & .000 & 1.426 \\
\hline
\end{tabular}

Berdasarkan nilai tabel DW (Durbin Watson) pada taraf signifikansi $5 \%$ dl adalah 1,5189 dan du adalah 1,6540 hasil uji autokorelasi menunjukkan nilai DW (Durbin Watson) sebesar 1,426 dan nilai tersebut berada $\mathrm{du}<\mathrm{d}<4-\mathrm{du}$ atau $1,6540<1,426<2,2727$, maka dapat disimpulkan bahwa tidak terjadi autokorelasi positif atau negatif pada model regresi linier berganda.

Tabel 4. Hasil SPSS Uji Multikolinieritas

\begin{tabular}{|c|c|c|c|c|c|c|c|}
\hline \multirow[b]{2}{*}{ Model } & \multirow[b]{2}{*}{ B } & \multirow{2}{*}{ Std. Error } & \multicolumn{2}{|c|}{ Coefficients } & \multirow[b]{2}{*}{ Sig. } & \multicolumn{2}{|c|}{ Collinearity Statistics } \\
\hline & & & Beta & $t$ & & Tolerance & VIF \\
\hline 11 (Constant) & & 2.441 & & -1.218 & .228 & & \\
\hline & -2.973 & & & & & & \\
\hline Literasiekonomi & .670 & .059 & .731 & 11.442 & .000 & .698 & 1.434 \\
\hline Kel. temansebaya & .250 & .092 & .202 & 2.707 & .009 & .510 & 1.962 \\
\hline Kontroldiri & .127 & .074 & .114 & 1.714 & .092 & .640 & 1.562 \\
\hline
\end{tabular}

(Sumber : Lampiran Hasil pengolahan data dengan SPSS 17.0)

Tabel menunjukkan bahwa nilai VIF yaitu 1.434 untuk variabel literasi ekonomi, 1.962 untuk kelompok teman sebaya dan 1.562 untuk kontrol diri dan nilai tolerance diatas 0,10 yaitu 0,698 untuk variabel literasi ekonomi, 0,510 untuk kelompok teman sebaya, dan 0,640 untuk variabel kontrol diri, maka dapat disimpulkan tidak terdapat gejala multikolinieritas sehingga hasil perhitungan model persamaan regresi akurat untuk memberikan 


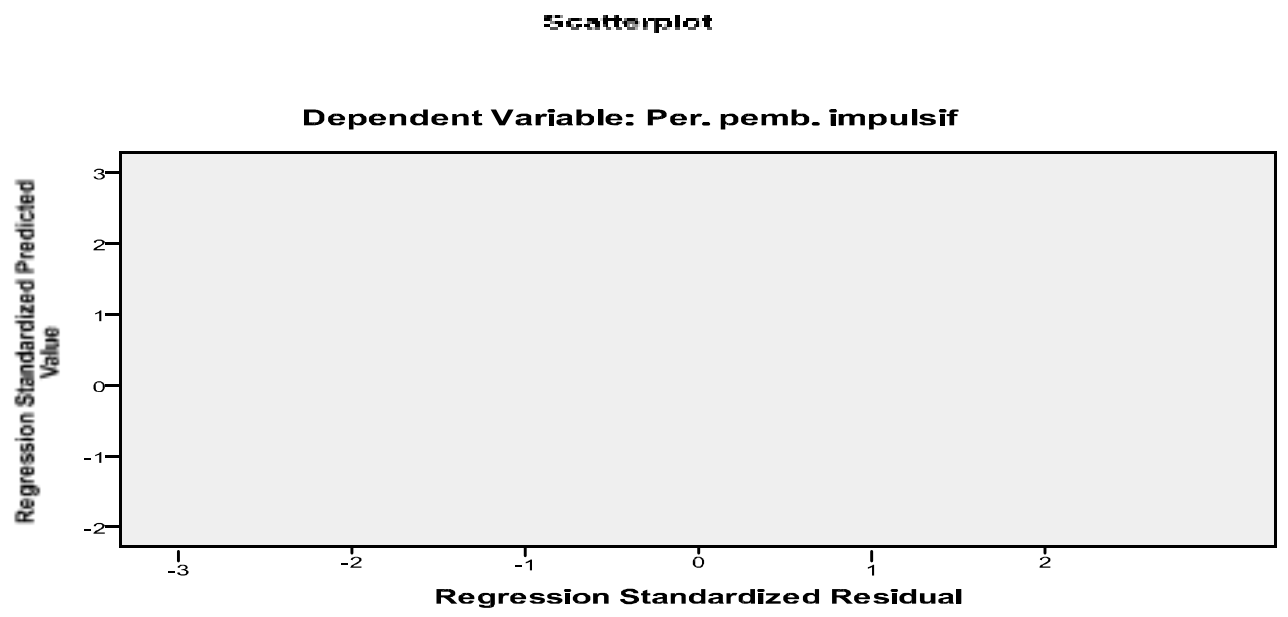

Gambar 1. Hasil SPSS Uji Heteroskedastisitas

Terlihat pada tampilan grafik scatterplot tersebut bahwa tidak terdapat pola tertentu yang teratur dan titik-titik menyebar di atas dan di bawah angka 0 pada sumbu $Y$ secara acak, maka tidak terjadi heteroskedastisitas

\section{Pembahasan}

Berdasarkan hasil penelitian, maka dapat disimpulkan bahwa literasi ekonomi kelompok teman sebaya dan kontrol diri secara bersamasama berpengaruh secara parsial maupun simultan terhadap perilaku pembelian impulsif produk fashion mahasiswa Jurusan Pendidikan Ekonomi Undiksha. Dalam literasi ekonomi berpengaruh positif dan signifkan terhadap perilaku pembelian impulsif produk fashion. Oleh karena itu untuk mengantisipasi perilaku pembelian impulsif, bisa dilakukan dengan memiliki literasi ekonomi yang memadai melalui pemahaman terhadap ilmu ekonomi. Dalam literasi ekonomi akan memberikan mereka ilmu mengenai bagaimana cara mengelola pendapatan untuk kepentingan berkonsumsi. Menurut Prasetijo dan Ihalauw (2005), "pengetahuan mengenai perilaku konsumen dapat meningkatkan kemampuan pribadi seseorang untuk menjadi konsumen yang efektif."

Demikian pula kelompok teman sebaya berpengaruh positif dan signifikan terhadap perilaku pembelian impulsif produk fashion mahasiswa Jurusan Pendidikan Ekonomi Undiksha. Hal ini berarti semakin banyak interaksi yang dilakukan dalam suatu atau model persamaan regresi homoskedastisitas.

kelompok atau teman akan berpengaruh terhadap perilaku pembelian impulsif melalui informasi yang diterima dari kelompoknya. Hal ini di dukung oleh pendapat Lusardi (2010) bahwa teman sebaya (peer) merupakan salah satu kunci dalam pemberian informasi sekaligus pertimbangan dalam pengambilan keputusan dalam pembelian produk. Melalui komunikasi dan informasi akan terjadi berupa perubahan pendapat, sikap dan perilaku. Perilaku belanja dan perilaku konsumsi individu dalam kelompok dapat dipengaruhi karena adanya informasi (informational influence) yang diterima dan dapat dipercaya dari rekan-rekan anggota dan kelompoknya.

Demikian pula kontrol diri berpengaruh positif dan signifikan terhadap perilaku pembelian impulsif produk fashion mahasiswa Jurusan Pendidikan Ekonomi Undiksha. Hal ini berarti semakin baik kontrol diri mahasiswa dalam melakukan pembelian maka menurunkan perilaku pembelian impulsif atau pembelian yang tidak terencana. Sebaliknya jika kemampuan kontrol diri mahasiswa kurang baik akan meningkatkan perilaku pembelian impulsif. Hal ini di dukung oleh pendapat Chaplin. Menurut Chaplin (2002) 
kontrol diri adalah kemampuan untuk membimbing tingkah lakunya sendiri, kemampuan untuk menekan atau merintangi impuls-impuls atau tingkah laku yang impulsif.

\section{SIMPULAN DAN SARAN}

Literasi ekonomi berpengaruh positif dan signifikan terhadap perilaku pembelian impulsif produk fashion mahasiswa Jurusan Pendidikan Ekonomi Undiksha. Hal ini berarti semakin tinggi kemampuan literasi ekonomi mahasiswa Jurusan Pendidikan Ekonomi Undiksha maka dapat menurunkan tingkat perilaku pembelian impulsif produk fashion mahasiswa Jurusan Pendidikan Ekonomi Undiksha. Sebaliknya, jika literasi ekonomi mahasiswa Jurusan Pendidikan Ekonomi Undiksha rendah maka tingkat perilaku pembelian impulsif mahasiswa meningkat.

Kelompok teman sebaya berpengaruh positif dan signifikan terhadap perilaku pembelian impulsif produk fashion mahasiswa Jurusan Pendidikan Ekonomi Undiksha. Hal ini berarti semakin banyak atau intens interaksi yang dilakukan dalam suatu kelompok atau teman akan berpengaruh terhadap perilaku pembelian impulsif melalui informasi yang diterima dari kelompoknya. Sebaliknya jika semakin sedikit intraksi yang dalam suatu kelompok maka menurun pula perilaku pembelian impulsif produk fashion mahasiswa Jurusan Pendidikan Ekonomi Undiksha.

Kontrol diri berpengaruh positif dan signifikan terhadap perilaku pembelian impulsif produk fashion mahasiswa Jurusan Pendidikan Ekonomi Undiksha. Hal ini berarti semakin baik kontrol diri mahasiswa dalam melakukan pembelian maka menurunkan perilaku pembelian impulsif atau pembelian yang tidak terencana. Sebaliknya jika kemampuan kontrol diri mahasiswa kurang baik akan meningkatkan perilaku pembelian impulsif.

Literasi ekonomi, kelompok teman sebaya dan kontrol diri berpengaruh signifikan (simultan) terhadap variabel terikat yaitu perilaku pembelian impulsif. Berdasarkan simpulan di atas maka dapat dikemukakan beberapa saran, (1) Bagi Mahasiswa, diharapkan bagi mahasiswa yang telah memiliki literasi ekonomi mengaplikasikan ilmu-ilmu ekonomi secara efektif agar terhindar dari perilaku pembelian impulsif atau pembelian yang tidak terencana (terduga). Selain literasi ekonomi mahasiswa juga diharapkan lebih selektif dalam melakukan pembelian suatu produk agar sesuai dengan kemampuan ekonomi yang dimiliki sebagai seorang mahasiswa. (2) Bagi Peneliti Lain, memungkinkan untuk meneliti kembali variabel lain yang berpengaruh secara positif terhadap perilaku pembelian impulsif berdasarkan teori yang telah diungkapkan. Hal ini dilakukan untuk menyempurnakan kembali penelitian mengenai perilaku pembelian impulsif. Peneliti lain juga diharapkan dapat mengungkap penemuan-penemuan baru yang bisa menunjang penelitian terdahulu.

\section{DAFTAR PUSTAKA}

Adiningsih, Kadarusman. (2008). Teori Ekonomi Mikro Edisi Kedua. BPFE: Yogyakarta

Ahmadi, Abu \& Sholeh, Munawar. (2005). Psikologi perkembangan. Jakarta: PT Rineka Cipta

Ali, M \& Asrori, M. (2005). Psikologi Remaja: Perkembangan Peserta Didik. Jakarta: Bumi Aksara

Ariani, Fika dan Sumaryono. 2008. "Pembelian Impulsif Ditinjau dari Kontrol Diri dan Jenis Kelamin Pada Remaja". Jurnal Psikologi Proyeksi. Vol. 3 No. 1. hlm. 46-57. Diakses tanggal 15 Desember 2015.

B.T., Syamsul. (2010). Psikologi Pendidikan Berbasis Analisis Empiris Aplikatif. Jakarta: Kencana Chaplin, JP. (2002). Kamus Lengkap Psikologi. Terjemahan Dr. Kartini Kartono. Jakarta: PT Raja Grafindo Persada

Damsar. (2012). Pengantar Sosiologi Politik Edisi Revisi. Jakarta: Kencana

Eun Joo, Park. 2006. "A structural model of fashion-oriented impulse buying behavior. Journal of Fashion Marketing and Management". Vol. 10 No. 4. Diakses tanggal 10 Januari 2016.

Firmansyah $\mathrm{H}$. Pernando, $\mathrm{R}$ dan Awaludin, A. (2010). Advance Learning Economic 1. Bandung : Facil 
Fudyartana, Ki. (2012). Psikologi Perkembangan. Pustaka Pelajar : Jogjakarta

Frank P, Albritton. 2006. "Performance on Tests of Economic Literacy: A: Comparison Of Face-to-Face with Online Instruction. First Monday (peer-reviewed journal on the internet”). Vol. 11 No. 10. Diakses tanggal 8 Desember 2015.

Ghufron, Nur M. \& Risnawita, Rini. (2014). Teori-Teori Psikologi. Yogyakarta: Ar-ruzz

Gunarsa, Singgih D, Gunarsa, D Singgih, Yulia. (2004). Psikologi Praktis: anak, remaja dan keluarga. Jakarta: Gunung Mulia

Hoyri S, Imam. 2014. "Kontrol Diri dan Perilaku Konsumtif pada Siswa SMA (Ditinjau dari Lokasi Sekolah)." Jurnal Online Psikologi. Vol. 2 No. 1. hlm. 46-61. Diakses tanggal 15 Desember 2015.

Kotler, Philip \& Armstrong, Gary. (2008). Prinsip-Prinsip Pemasaran Edisi Keduabelas Jilid 1. Alih bahasa: Bob Sabran. Jakarta: Erlangga

Kotte \& Witt. 2005. Chance and Challenge : Assessing Economic Literacy. Technical University Dresden School of Economics. http://www.waxmann.com/fileadmin /media/zusatztexte/postlethwaite/k otte.pdf. diakses tanggal 8 Januari 2016

L. G., Schiffman, Leslie. L, Kanuk. (2007). Consumer Behavior. America: Pearson Prentice Hall

Lili, Adi Wibowo. 2008. Menata Produk. Makalah, Pendidikan dan Latihan Profesi Guru (PLPG) Bidang Keahlian Manajemen Bisnis. Bandung: Universitas Pendidikan Indonesia

Lisda, Rahmasari. 2010. Menciptakan Impulse Buying. Majalah IImiah Informatika. Vol. 1 No. 3. hlm. 5668. Diakses tanggal 20 Desember 2015.

Mangkunegara, Prabu A. (2000). Perilaku konsumen. Bandung : PT. Eresco

Mayasari, Mila. 2012. Pengaruh Penguasaan Konsep Ekonomi, Konformitas Teman Sebaya dan Emosi terhadap Perilaku
Pembelian Impulsif untuk Produk Aksesoris Remaja pada Siswa Kelas XI Jurusan IPS SMA N 10 Yogyakarta. Skripsi. Yogyakarta: Universitas Negeri Yogyakarta

Mowen, John C \& Michael, Minor. (2002).

Perilaku Konsumen Jilid 1. Alih

Bahasa: Lina Salim. Jakarta:

Erlangga

Prasetijo, Ristiyanti \& Ihalauw, John. (2005). Perilaku Konsumen. Yogyakarta: ANDI

Sandy, Bagus. 2013. "Pengaruh Pendidikan Ekonomi Keluarga

Terhadap Perilaku Konsumsi

Dimediasi Literasi Ekonomi dan

Gaya Hidup pada Mahasiswa

Fakultas Ekonomi Universitas Negeri Malang Angkatan 2011" Ekuitas Jurnal Pendidikan Ekonomi. Jurnal Volume 1, Nomor 1, Desember 2013.

Sarah, Dira. 2014. "Peran Kontrol Diri Terhadap Pembelian Impulsif pada Remaja Berdasarkan Perbedaan Jenis Kelamin di Samarinda". eJournal Psikologi. Vol. 1 No.3.hlm.313-323. Diakses tanggal 8 Desember 2015.

Sina, Peter G. 2012. "Analisis Literasi Ekonomi". Jurnal Economia. Vol. 8 No. 2. hlm. 135-143. Diakses tanggal 4 Januari 2016.

Sumartono. 2002. Terperangkap dalam Iklan. Bandung: Alfabeta

Suparmin, Astuti, Dwi dan Sawiji, Hery. 2013. Ekonomi untuk SMA dan MA Kelas $X$. Surakarta: Mediatama

Suryani, Tatik. 2013. Perilaku Konsumen di Era Internet: Implikasinya pada Strategi Pemasaran

Sutisna. (2002). Perilaku Konsumen dan Komunikasi Pemasaran. Bandung: PT Remaja Rosdakarya

Umar, Husein. 2008. Desain Penelitian Kualitatif dan Kuantitatif. Jakarta: Raja Grafindo Persada

Vembriarto, S.T. (2003). Sosiologi Pendidikan. Jakarta: PT Gramedia

Wijaya, Toni. 2013. Metodologi Penelitian Ekonomi dan Bisnis Teori dan Praktek. Yogyakarta: Graha IImu 
